\title{
MOTHERS' EXPERIENCES WHEN THEIR INFANTS WERE DIAGNOSED WITH CLEFT LIPS AND/OR PALATES
}

\section{Liezel Ter Poorten}

B. Communication Pathology

Department Communication Pathology, University of Pretoria

\section{Brenda Louw}

BA Log, MSc, DTO, D Phil

Professor, Department Communication Pathology, University of Pretoria

Corresponding author: blouw@postino.up.ac.za

Keywords: Cleft lip and/or palate; Craniofacial team; Pre- and postnatal diagnosis; Support systems

\begin{abstract}
Traditionally the diagnosis of cleft lip and palate was made at birth or soon thereafter, but modern technology has led to the identification of cleft lip prenatally. The aim of this study was to describe 16 mothers' experiences of pre- and postnatal diagnosis of their infants' cleft lip and palate, and to develop clinical guidelines for craniofacial team members, to meet parental expectations and needs in both pre- and postnatal periods. In order to provide the best possible care to each affected child and the most effective support to each mother, it is of the utmost importance that craniofacial teams have guidelines to assist them in developing a more accountable, effective and sensitive service to these mothers. An exploratory, descriptive quantitative survey research design was selected to describe mothers' reactions to and perceptions of the pre-and postnatal diagnosis. Scheduled structured interviews were used as a data collecting technique. The results indicated that, irrespective of the time of diagnosis, the mothers required support that included emotional support, information, interaction with other parents of children with clefts, and a team approach. This study emphasised the importance of understanding parental preferences in order to enhance the team approach and also highlighted the need for further research.
\end{abstract}

\section{OPSOMMING}

Tradisioneel is die diagnose van gesplete lip en verhemelte met geboorte, of kort daarna gemaak, maar moderne tegnologie het gelei tot die identifikasie van gesplete lip prenataal. Die doel van hierdie studie was om 16 moeders se ervarings van die pre- en postnatale diagnose van hul babas se gesplete lip en verhemelte, te beskryf, en om sodoende kliniese riglyne te ontwikkel vir kraniofasiale spanlede, ten einde hulle toe te rus om aan ouers se behoeftes te voldoen in die pre-en postnatale periodes. Ten einde die beste moontlike versorging te bied aan elke kind wat geaffekteer is, en aan elke moeder die mees effektiewe ondersteuning te gee, is dit uiters belangrik dat die kraniofasiale spanlede oor riglyne sal beskik wat hulle sal ondersteun om 'n meer verantwoordbare, effektiewe en sensitiewe diens te lewer. 'n Beskrywende kwantitatiewe opname navorsingsontwerp is gekies om moeders se reaksies en persepsies van die preen postnatale diagnose te beskryf. Geskeduleerde, gestruktureerde onderhoude is gebruik as data opname tegniek. Die resultate het aangedui dat ongeag die tyd van diagnose, moeders ondersteuning benodig. Hierdie ondersteuning sluit in emosionele ondersteuning, inligting, interaksie met ander ouers van kinders met gesplete lip en/of verhemelte, en 'n spanbenadering. Die resultate het die behoefte aan verdere navorsing na vore gebring.

\section{INTRODUCTION}

Traditionally the diagnosis of cleft lip and palate was made at birth or thereafter, but modern technology led to the identification of cleft lip prenatally (Blumenfeld, Blumenfeld \& Bronshtein, 1999:105). This new development holds exciting prospects, but also entails challenges in adapting and sensitising services to 
address the needs of this new population to be served by the health care professionals, in an effective and accountable manner (Louw \& Kritzinger, 1998:18). New tests and diagnostic procedures in genetic, medical and dental fields may provide valuable information regarding the diagnosis of multiple anomaly syndromes often found among infants with cleft lip and palate (Louw \& Kritzinger, 1998:19). In the case of cleft lip or cleft lip and palate, transvaginal sonography is often used as a prenatal diagnostic method, and according to Blumenfeld et al. (1999:106) transvaginal sonography can detect foetal malformations at 14- 16 weeks gestation with an accuracy of $95 \%$, and cleft lip has been diagnosed as early as 11 weeks gestation. For some families at risk, these procedures might provide reassurance that the foetus is unaffected. When prenatal diagnostic testing reveals an affected foetus, it leaves the family with different options, including a difficult decision regarding the management of the pregnancy (Louw \& Kritzinger, 1998:13). Since the number of women undergoing prenatal assessments continues to increase, many couples might be faced with the option of terminating the pregnancy. This issue places significant stress on the parents, as feelings of guilt and doubt might play a role during the decision-making process (Simpson \& Elias, 1993:54).

These recent advances have introduced new knowledgebased dilemmas. These ethical dilemmas have highlighted the critical need for health professionals to understand patient preferences for information and control with respect to prenatal diagnosis (Berk, Marazita \& Cooper, 1999:32). The ethics of abortion could be difficult to resolve, as these discussions might be complicated by religious, legal, and political arguments (Batshaw, 1997:67). Health care providers should assist parents, providing them with all the objective options to make their own informed decisions.

Limited research about the prenatal diagnosis of cleft lip and palate could be traced. Bronshtein, Blumenfeld and Blumenfeld (1996:105) conducted a study in Israel where transvaginal sonography was administered at 13-16 weeks gestation to detect a cleft of the lip, but the 15 cases where cleft lip was detected, only one couple chose not to terminate the pregnancy (Bronshtein et al. 1996:106). The findings of a similar study conducted in the USA by Jones (1999:108) appears to contradict those of the Israeli study in that of the eight American cases who were identified before 22 weeks gestation, six women continued with their pregnancies and two did not. These results are in striking contrast to those reported by Bronshtein et al. (1996:106) and could be attributed to e.g. context, religious differences and diagnostic methods.

For parents who do not want to terminate the pregnancy, the prenatal period provides them with the opportunity to prepare themselves emotionally, physically and financially for the challenge that lies ahead (Clark \& De Vore, 1989 in Pelser, 1998:86). This period also provides time for the multidisciplinary health care team to plan the management and delivery of the infant with the parents, and to prepare for the special needs of the newborn period (Batshaw, 1997:71).

Cleft lip/palate is known to have a pervasive effect on all aspects of development requiring a multidisciplinary team approach to meet the needs of these children and their parents (Louw \& Kritzinger, 1998:18). Although consensus exists in the literature that a team approach is most beneficial for the child with cleft lip/palate (Shprintzen \& Bardach, 1995:11), it is this very aspect which is absent at the most crucial time, namely the diagnosis, as there are seldom teams involved in the diagnosis of cleft lip and palate, whether it is made preor postnatally. The communication of "Bad News" can be very difficult for the informer and devastating for the parents (Krahn, Hallum \& Kime, 1993:578). Few guidelines exist for practitioners who wish to meet patient and family expectations for clear and caring communication (Strauss, Sharp, Lorch \& Kachalia, 1993:6). Diagnosis is a lengthy process of preparation and management, whether it is made pre- or postnatally, prior to or following the birth. It is therefore of the utmost importance that the team approach should be followed in the diagnosis and not only in the management of the disorder when it occurs. Families with affected newborns, whether diagnosed pre- or postnatally, are acutely in need of support and information so that they can negotiate this difficult transition. The danger is that if parents are not able to make the emotional adjustments, their unresolved feelings are likely to reappear and negatively influence their parenting (Pope, 1999:37).

Although the emotions experienced by mothers after the birth of an infant with a cleft lip and palate, have been 
described in the literature (Pope, 1999:36), limited research has been conducted regarding emotions surrounding the diagnosis of a cleft lip and palate, regardless the time thereof (Strauss, et al. 1993:3; Bronshtein et al. 1996:486; Jones, 1999:107). The following question arises: what are the experiences of mothers of infants diagnosed with cleft lips and/or palates at different stages, in a local South African context? The purpose of the research was therefore to explore the experiences of a group of mothers when their infants were diagnosed with cleft lips and/or palates, in order to formulate guidelines for health care providers to meet parental expectations and needs in both the pre-natal and postnatal periods.

\section{METHODOLOGY}

\section{Research Aim}

The main aim of the study was to examine a group of mothers' experiences when their infants were diagnosed with cleft lips and/or palates, pre- or postnatally. The following objectives outlined the means by which the principle aim of the study was investigated:

To explore and describe mothers' reactions to, and perceptions of, the diagnosis of their children's cleft lips and/or palates.

To provide guidelines for health care providers for coping with such diagnoses and mothers' experiences.

\section{Research Design}

An exploratory, descriptive quantitative survey research design was employed to explore and describe mothers' reactions to, and perceptions of, the pre-or postnatal diagnoses of their infants' cleft lip and/or palate (Bless \& Higson-Smith, 1995:373). This design looks closely at current phenomena, measures the characteristics of a sample at one point in time and allows inferences to be drawn about a particular population (Leedy, 1997:191).

Surveys are the collection of information where the emphasis is on the frequency of answers to the same question by different people and are often used to determine people's beliefs, attitudes, opinions, characteristics, knowledge, and past or present behaviour (Bless \& Higson-Smith, 1995:43; Neuman,
1997:111). A survey therefore served as an appropriate information gathering tool in exploring mothers' experiences of the diagnoses of their infants' cleft lips and/or palates.

Scheduled structured interviews (Leedy, 1997:199) were used to conduct the descriptive survey research. One of the most important advantages of this technique is that it helps overcome misunderstandings and misinterpretations of words or questions, and as a result, the answers provided are clearer (Bless \& Higson-Smith, 1995:107). A disadvantage of this approach is, however, that the interviewer is not able to pursue topics of interest that arise during the interviews (Stein \& Cutler, 1996:415). Overall, however, this method was well suited to the issues explored, as the interviewer could ensure that sensitive questions were not omitted, and thus more detailed descriptions could be made. Descriptive statistics were used to describe the data (Stein \& Cutler, 1996:221).

\section{Subjects}

Two groups of subjects participated in the study, namely mothers of infants whose cleft lips and/or palates were diagnosed prenatally and those whose infants were diagnosed postnatally. The first group of subjects, namely those whose infants were diagnosed prenatally, was selected according to the principle of nonprobability sampling. Due to the limited number of subjects in this group, accidental sampling was used (Leedy, 1997:97). This method encompasses the consideration of all available cases (Bless \& Higson-Smith, 1995:105). The mothers of infants who were diagnosed postnatally were selected by loosely matching them to the first group. In the current study, the variables of the type of clefts and ages of the infants were matched. This was done in order to provide a generally homogenous grouping of the subjects, and to ensure that parental reactions were shaped by similar circumstances. All 16 subjects who participated in the study attended the same multidisciplinary clinic and were served by the same team of health care providers. Eight of these were mothers of infants with cleft lips and/or palates who received the diagnosis prenatally, and eight subjects were mothers who received the diagnosis postnatally. The subjects are described in tables 1 and 2 . 
Table 1: Description of children of the subjects $(n=16)$

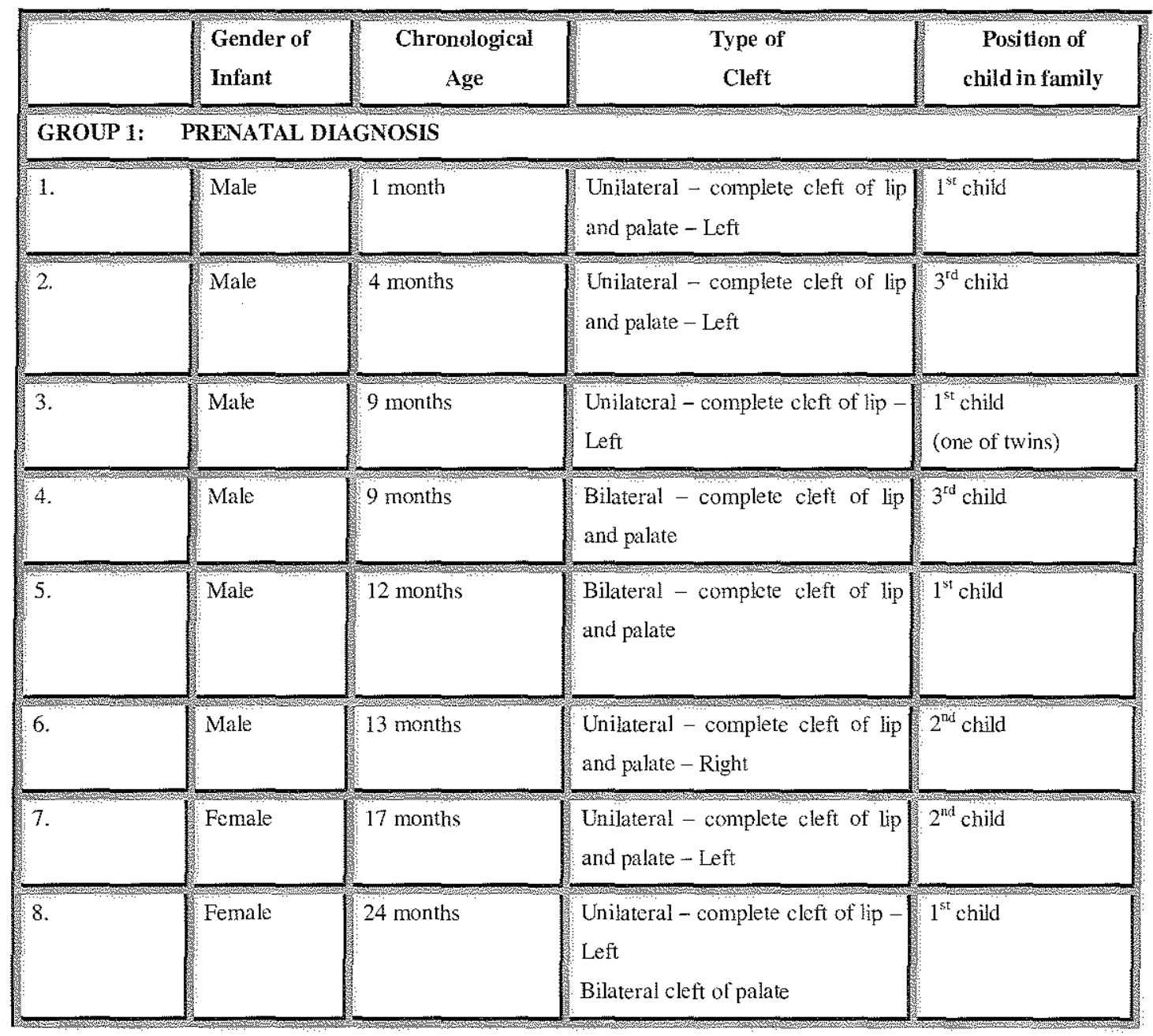

\begin{tabular}{|c|c|c|c|c|}
\hline \multicolumn{5}{|c|}{ GROUP 2: POSTNATAL DIAGNOSIS } \\
\hline 1 & Male & 2 months & $\begin{array}{l}\text { Unilateral - complete cleft of lip } \\
\text { and palate - Left }\end{array}$ & $3^{\text {rd }}$ child \\
\hline 2 & Male & 5 months & $\begin{array}{l}\text { Unilateral - complete cleft of lip } \\
\text { and palate - Right }\end{array}$ & $3^{\text {rd }}$ child \\
\hline 3. & Male & 9 months & $\begin{array}{l}\text { Unilateral - complete cleft of lip - } \\
\text { Left }\end{array}$ & $1^{\text {st }}$ child \\
\hline 4. & Female & 12 months & $\begin{array}{l}\text { Bilateral - complete cleft of lip } \\
\text { and palate }\end{array}$ & $2^{\text {nd }}$ child \\
\hline 5. & Male & 12 months & $\begin{array}{l}\text { Bilateral - complete cleft of lip } \\
\text { and palate }\end{array}$ & $2^{\text {nd }}$ child \\
\hline 6. & Female & 13 months & $\begin{array}{l}\text { Unilateral - complete cleft of lip } \\
\text { and palate - Right }\end{array}$ & $1^{\text {st }}$ child \\
\hline 7. & Male & 20 months & $\begin{array}{l}\text { Unilateral - complete cleft of lip } \\
\text { and palate - Left }\end{array}$ & $2^{\text {nd }}$ child \\
\hline 8. & Male & 22 months & $\begin{array}{l}\text { Unilateral - complete cleft of lip - } \\
\text { Left } \\
\text { Bilateral cleft of palate }\end{array}$ & $1^{\text {st }}$ child \\
\hline
\end{tabular}


The higher incidence of males with clefts (as seen in table 1) reflects what is cited in the literature (Shprintzen, 1997:13). The most common type of cleft namely, left unilateral complete cleft of the lip and palate, was also evident in 7 of the infants. (Shprintzen, 1997:13). The mothers' ages ranged from 25-35 years. All except one had completed high school education. Most also had some form of tertiary education and had a variety of professions with only two being full time home executives.

\section{Data collection instrument}

A scheduled structured interview was used as the data collection instrument. In order to minimise threats to valid and objective research, it was ensured that the questionnaire contained items pertinent to the survey's objectives and the content of the questionnaire was based on a literature review of cleft lip and palate and issues related to its diagnosis (Blumenfeld et al. 1999:105; Jones, 1999:107; Strauss et al. 1993:4). This enhanced the content validity of the questionnaire (Leedy, 1997:33). Furthermore the face validity of the questionnaire was controlled for by developing the format of the questionnaire according to specific guidelines available in the literature (Neuman, 1997:110; Bless \& Higson-Smith, 1995:109; Leedy, 1997:33). The questionnaire consisted of six sections, namely biographical information, diagnosis of the cleft, reactions to the diagnosis of the cleft, support systems and recommendations for treatment of parents in the future, and included 28 questions, of which three were yes/no questions, eight were yes/no/uncertain questions, four were multiple choice closed questions and thirteen were open-ended questions (Bless \& Higson-Smith, 1995:112). The questionnaire was compiled in both English and Afrikaans.

The range of the questionnaire ensured that relevant information pertaining to the research question was covered, and the structured nature thereof limited interviewer skills and bias from influencing the data obtained (Leedy, 1997:199).

\section{Reliability and Validity}

The objective of data collection is to produce reliable data (Mouton, 1996:111). According to Neuman (1997:112) reliability is also a precondition for measurement validity, therefore by maximising the reliability of questions and the validity of survey measures can be increased. Pretesting was done to assess the structure and content of the questionnaire and to ensure that the interview technique was free of bias (Neuman, 1997:113). Two mothers of children with cleft lip and/or palate, who were trained Cleft Palate Support Group members, acted as participants. The purpose of the research as well as of the pretest was explained to the participants, before they were interviewed separately. They were requested to carefully consider all questions asked of them in the structured interview and to make comments and suggestions regarding the formulation of the questions, order of presentation, choices provided and the response format, in order to enhance face validity. The participants were also requested to comment on the content of the six sections of the questionnaire to control content validity. The pretest produced meaningful suggestions, which precipitated various changes to the questionnaire.

To enhance objectivity and accuracy during data analysis, interviews were audio-recorded with the subjects' consent, to further improve reliability. The limited sample size decreased the external validity and therefore conclusions could not be generalised to the broader population, but could only serve as a preliminary step in exploring the subjects' experiences (Leedy, 1997:34)

\section{PROCEDURES}

\section{Data Collection}

Individual interviews were conducted with the 16 subjects, at a time and venue of their convenience. Each interview lasted approximately 45 minutes. Questions were read verbatim to ensure standardisation (Leedy, 1997:199). When required, probing was done, to make the purpose of a question more succinct and to obtain additional, more clarifying information (Leedy, 1997:199).

\section{Data Recording and Analysis}

Answers provided by the subjects were recorded onto the questionnaire during the interview. Descriptive statistics were applied by using the SAS (Statistical Analysis System) computer program to analyse the data (Stein \& Cutler, 1996:221, 313). Frequencies served as 
Table 2: Description of the subjects $(n=16)$

\begin{tabular}{|c|c|c|c|c|c|c|}
\hline & Age & $\begin{array}{l}\text { Education } \\
\text { Level }\end{array}$ & Occupation & Time of diagnosis & $\begin{array}{l}\text { Geographic } \\
\text { location }\end{array}$ & $\begin{array}{l}\text { First } \\
\text { Language }\end{array}$ \\
\hline \multicolumn{7}{|c|}{ GROUP 1: PRENATAL DIAGNOSIS } \\
\hline 1. & 32 years & $\begin{array}{l}\text { Tertiary } \\
\text { Diploma }\end{array}$ & Teacher & Prenatally & Urban & Afrikaans \\
\hline 2. & 25 years & Std. 8 & $\begin{array}{l}\text { General caregiver } \\
\text { Old age home }\end{array}$ & Prenatally & Rural & Afrikaans \\
\hline 3. & 34 years & $\begin{array}{l}\text { Tertiary } \\
\text { Diploma }\end{array}$ & Travel Agent & Prenatally & Urban & English \\
\hline 4. & 38 years & High school & Home executive & Prenatally & Rural & Afrikaans \\
\hline 5 & 38 years & $\begin{array}{l}\text { Tertiary } \\
\text { Diploma }\end{array}$ & Chef & Prenatally & Urban & English \\
\hline 6. & 26 years & High school & Home executive & Prenatally & Rural & Afrikaans \\
\hline 7. & 32 years & Tertiary Degree & Chemist & Prenatally & Urban & English \\
\hline 8. & 35 years & Tertiary Degree & Attorney & Prenatally & Urban & English \\
\hline 1. & 36 years & $\begin{array}{l}\text { Postgraduate } \\
\text { degree }\end{array}$ & Teacher & Postnatally & Rural & Afrikaans \\
\hline 2. & 36 years & $\begin{array}{l}\text { Tertiary } \\
\text { Diploma }\end{array}$ & Financial clerk & Postnatally & Urban & Afrikaans \\
\hline 3. & 27 years & $\begin{array}{l}\text { Tertiary } \\
\text { Diploma }\end{array}$ & Hairdresser & Postnatally & Rural & Afrikaans \\
\hline 4. & 29 years & High school & Bookkeeper & Postnatally & Urban & Afrikaans \\
\hline 5 & 28 years & High school & Administrative clerk & Postnatally & Urban & Afrikaans \\
\hline 6. & 30 years & High school & Bank clerk & Postnatally & Urban & Afrikaans \\
\hline 7. & 30 years & $\begin{array}{l}\text { Tertiary } \\
\text { Diploma }\end{array}$ & Hairdresser & Postnatally & Urban & English \\
\hline 8. & 31 years & $\begin{array}{l}\text { Tertiary } \\
\text { Diploma }\end{array}$ & Teacher & Postnatally & Urban & Afrikaans \\
\hline
\end{tabular}


raw data and frequency tables were compiled in order to make the results clear and meaningful (Neuman, 1997:293). Content analysis (Kerlinger, 1986: 477-481) was conducted on the open-ended questions.

\section{Research Ethics}

Ethical issues were addressed to protect the rights and welfare of the subjects participating in the study. The principles of ethics include simple considerations of fairness, honesty, openness of intent, disclosure of methods, the ends for which the research is executed, a respect for the integrity of the individual and an informed willingness on the part of the subject to participate voluntarily in the research activity (Leedy, 1997:116).

A letter of consent was sent to subjects to obtain their permission to participate in the study. The letter stipulated that all data would be treated confidentially and that their anonymity would be guaranteed. Furthermore it was stated that subjects could withdraw at anytime during the investigation. The aim and method of the investigation was explained briefly to ensure that the subjects understood the procedure and could therefore willingly make a decision as to whether or not to participate in the study. All subjects signed and returned a copy of the letter of consent, indicating their willingness to participate in the research and accepting the conditions thereof.

\section{RESULTS}

Mothers' perspectives of the diagnosiss of their children's cleft lip and/or palate

According to the results obtained, it appeared that the prenatal diagnosis was made between 12 and 31 weeks gestational age, with the majority (five) of the eight mothers received the diagnosis between 20 and 28 weeks gestation. These results are in apparent contrast with those of Bronshtein et al. (1996:486), reporting that most patients underwent transvaginal sonography at 1316 weeks gestation. It is, however, in closer accordance with the American study conducted by Jones (1999:108) who stated that the mean age of identification was between 22 and 24 weeks gestation. The specific techniques used might have influenced the stage of identification. This aspect could have influenced the parents' choice concerning the termination of the pregnancy. With regard to postnatal diagnosis, all the mothers received the diagnosis immediately after the baby's birth. The pre- and postnatal diagnoses were made relatively early, which gave parents time to prepare themselves, both medically and emotionally to cope with their infant with a cleft lip and/or palate (Louw \& Kritzinger, 1998:13).

The person who conveyed the diagnosis is presented in Table 3.

Table 3: Person conveying the diagnosis $(n=16)$

\begin{tabular}{|l|c|c|}
\hline $\begin{array}{c}\text { PERSON CONVEYING } \\
\text { THE DIAGNOSIS }\end{array}$ & $\begin{array}{c}\text { PRENATAL DIAGNOSIS } \\
\text { (Group 1) } \\
\text { (Number of respondents) }\end{array}$ & $\begin{array}{c}\text { POSTNATAL DIAGNOSIS } \\
\text { (Group 2) } \\
\text { (Number of respondents) }\end{array}$ \\
\hline Gynaecologist & 6 & 3 \\
\hline Paediatrician & 0 & 1 \\
\hline Ganaecologist \& & 2 & 0 \\
\hline Nurse & 0 & 4 \\
\hline General Practitioner & 0 & 0 \\
\hline
\end{tabular}


Gynaecologists were involved in the conveyance of the diagnosis in most of the cases where the diagnosis was made prenatally whilst paediatricians played a significant role in postnatal diagnoses and communicated the diagnosis in most of the cases. In four of the cases both the gynaecologist and paediatrician played some role in conveying the diagnosis at birth. These results supported the findings of Strauss et al. (1993:13) who stated that the gynaecologist and paediatrician most commonly served in the role of informing parents about the child's cleft.

The support person present at delivery of the diagnosis is presented in Table 4.

Table 4: Support persons during diagnosis $(n=16)$ which was in accordance with the findings of Strauss et al. (1993:7). This left them feeling uncertain about the implications of the diagnosis. Regarding the conveyer's empathy, sensitivity and caring attitude, fourteen mothers reported that the conveyer was completely empathetic, sensitive and cared about their feelings. However, two subjects from group 2, felt that the conveyer did not care about their feelings at all. Fourteen of the mothers reported that they received sufficient information at the time of the diagnosis and also had an opportunity to ask questions. This result indicated that most of the conveyers were willing to share their knowledge about the anomaly, and were also willing to answer questions. Krahn et al. (1993:580) emphasised the importance of being well informed at the time of the diagnosis, as this influences parental perceptions of the anomaly, and could

\begin{tabular}{|c|c|c|}
\hline $\begin{array}{c}\text { SUPPORT PERSON } \\
\text { PRESENT }\end{array}$ & $\begin{array}{c}\text { PRENATAL DIAGNOSIS } \\
\text { (Group 1) } \\
\text { (Number of respondents) }\end{array}$ \\
\hline$>$ Fathers & $\begin{array}{c}\text { POSTNATAL DIAGNOSIS } \\
\text { (Group 2) } \\
\text { (Number of respondents) }\end{array}$ \\
\hline$>$ Family members & 4 & 7 \\
\hline
\end{tabular}

According to Table 4 most mothers had a support person present at the diagnosis, whether it was made pre- or postnatally. These results were positive compared to the findings of Krahn et al. (1993:580) who reported that 55\% of their subjects expressed a desire to have a support person present at the communication of the diagnosis. None of the subjects who received the diagnosis postnatally reported to have held their babies during the conveyance of the diagnosis. Krahn et al. (1993:580) emphasised the critical importance to parents of being able to hold and touch their babies before or during the informing process. The implications of not being able to hold and touch their infants could be detrimental to later bonding, and could influence the initial contact with the baby (Endriga \& Speltz, 1997:450).

The mothers reported experiencing the following feelings related to the manner in which the diagnosis was conveyed: Only ten of the mothers experienced the conveyer of the diagnosis to be in control of the situation, influence crucial decisions about the management of the pregnancy. Only ten mothers reported that the conveyer provided an opportunity for expressing their own feelings. This could be due to individual personalities, skills and qualities of the conveyers and how the individuals were able to deal with the communication of "Bad News" (Strauss et al. 1993:7).

Mothers' perceptions of the manner in which the diagnoses were imparted, were generally positive although it was clear that there were a number of issues that could have been handled in a more sensitive, caring manner (Strauss et al. 1993:6).

Although no differences were apparent between mothers who received the diagnoses prenatally and those who received it postnatally, it is interesting to note that the two mothers who reported extremely bad experiences regarding the conveyance of the diagnosis received it postnatally. One mother reported: "I could hear my baby 
struggling to breathe, and the doctor turned to me and said: 'The umbilical cord is round his neck, and, oh, he's got a harelip too.' I was so confused, and stunned by the insensitive manner in which she was talking to me, I could hardly believe it, but when / saw the tears in my husband's eyes, I knew that it was really true".

These results reflected a more positive trend than reported by Strauss et al. (1993:16) and Krahn et al. (1993:581). Parents who received the diagnosis in a favorable manner, from a person who cared, adapted better to the situation, were emotionally more in control, and were therefore more available to their child and his/ her special needs (Pope, 1999:37).

\section{Mothers' emotions regarding the communication of the diagnosis}
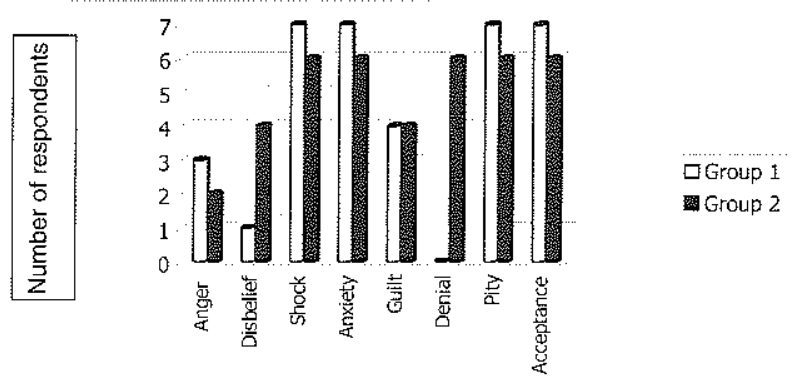

Group $1=$ Mothers who received the diagnosis prenatally

Group 2=Mothers who received the diagnosis postnatally

Figure 1: Emotions experienced at the conveyance of diagnosis $(n=16)$

It was clear that mothers who received the diagnosis prenataliy and those who received it postnatally, experienced similar ranges of emotions, and it was concluded that the time of diagnosis did not appear to influence the initial reactions and emotions of subjects. The diagnosis, whether made pre- or postnatally, was fearful because of its unexpectedness and suddenness (McWilliams, Morris \& Shelton, 1990:156). According to Pope (1999:37) experiencing these emotions is not a problem, but dealing with them successfully is crucial to mothers if they are to be able to provide a warm and responsive relationship with their child.

\section{Support systems}

The importance of good support systems and the crucial roles that family, friends and health care providers play in supporting parents with a child with a cleft, was overlooked and underestimated for several decades (Butler, 1994:87). Mothers reported that they received ample support from friends, husbands, relatives, physicians, support group parents and other professionals, immediately after receiving the diagnosis. However, mothers in the prenatal group (Group 1) felt that support group parents and other health care providers could have played a bigger role initially. Mothers who received the diagnosis postnatally (Group 2) felt that physicians and support group parents were less supportive than experienced by the mothers in Group 1, whilst they experienced other health care providers as being more supportive.

Tingey (1989:47) maintained that those who work with families of young children with an anomaly should direct some of their efforts towards ensuring better support systems for these families. Professionals were required to provide effective support, delivered through the quality of the relationship between the professionals and the family members (Tingey, 1989:43).

Information regarding the different team members and resources that mothers were referred to, is presented in Table 5.

It appeared that mothers in Group 1 were mostly referred to all the professionals involved in the team, whilst mothers in Group 2 were all referred to the surgeon and the paediatrician, and all kept the appointments. Mothers in Group 2, however, reported experiencing greater difficulties by not being referred to all the team members involved. This was attributed to the fact that many of the subjects who received the diagnosis postnatally, were not referred to a team early enough, and were therefore not involved with a team of health care providers from the outset. In addition, this limited the mothers' realisation of the importance of all the team members, as they were not introduced to them immediately after the birth of the child (Palmer \& Du Plessis, 1996:54).

It was concluded that the majority of the mothers received care from a variety of team members, and that mothers mostly kept these appointments. However, mothers who received the diagnosis postnatally, apparently required more assistance in coping with the team members involved with their child and his or her special needs. 
Table 5: Team members referred to and resources $(n=16)$

\begin{tabular}{|c|c|c|c|c|c|c|}
\hline \multirow[t]{2}{*}{$\begin{array}{l}\text { Team members and } \\
\text { resources referred to: }\end{array}$} & \multicolumn{3}{|c|}{ Prenatally (Group 1) } & \multicolumn{3}{|c|}{ Postnatally (Group2) } \\
\hline & Referred & Never followed up & Followed up & Referred & Never followed up & Followed up \\
\hline Surgeon & 8 & 0 & 8 & 8 & 0 & 8 \\
\hline Paediatrician & 8 & 0 & 8 & 8 & 0 & 8 \\
\hline Nurse & 8 & 0 & 8 & 7 & 0 & 7 \\
\hline $\begin{array}{l}\text { Speech Language } \\
\text { Therapist and Audiologist }\end{array}$ & 8 & 2 & 6 & 6 & 2 & 4 \\
\hline Support parents & 7 & 0 & 7 & 5 & 0 & 5 \\
\hline Psychologist & 7 & 7 & 0 & 7 & 3 & 4 \\
\hline Reacing material & 8 & 0 & 8 & 7 & 1 & 6 \\
\hline
\end{tabular}

Mothers experienced different reactions to having their needs met by the team members. Mothers in Group 1 felt that the nurse and the speech-language therapist and audiologist provided excellent support and assistance, whilst the psychologist was not supportive. Mothers in Group 2 also felt that nurses provided good care, but experienced a more positive reaction to the support provided by the psychologist than the mothers in Group 1, whilst they felt that the speech-language therapist was not as supportive. Although mothers experienced varying support from health care providers, they needed them to provide support at the right time, and in the right manner (Benton, Gross \& Messer, 1991:254).

\section{Mothers' reactions to, and perceptions of, the time of diagnosis}

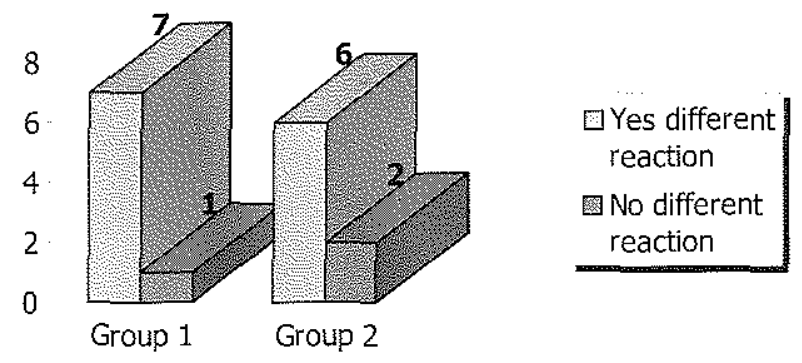

Figure 2: Different reactions to a different time of diagnosis $(n=16)$

It was clear that the responses of the mothers in the two groups, as to whether or not they would have reacted differently, had the diagnosis been made at another time, did not differ significantly. The mothers in group 1 felt that shock at receiving the diagnosis postnatally, as well as other reasons, would have made them react differently, whilst those in group 2 were divided over being either better prepared, or more distressed, at a prenatal diagnosis. What did, however, differ, was how mothers dealt with these emotions later, which could have been attributed to personal characteristics rather than to the specific time at which the diagnosis was made (Pope, 1999:38).

\section{Termination of pregnancy}

Out of the eight mothers in Group 1, only two reported that they would consider terminating a future pregnancy. One mother verbalised her concern for problems beyond those that could be recognised by the ultrasound, and the other expressed her concern in the light of the effect that another baby with a cleft would have on the rest of her family. Of the eight mothers in Group 2, only one stated that she might consider the termination of a future pregnancy, depending on whether other malformations were present or not. Factors such as religious and cultural values played an important role in the mothers' responses, but were not investigated.

These results were at odds with the findings of Bronshtein et al. $(1996: 486)$ that determined that 14 of the 15 mothers in their study chose to terminate the pregnancy, and with those of Blumenfeld et al. (1999:107) who found that 23 of the 24 mothers in their study chose to terminate. Jones (1999:108), however, revealed that only two of the eight mothers participating in her study chose to terminate, which was in closer accordance with the results obtained in the current study.

Mothers' recommendations regarding the conveyance of the diagnosis 
In response to an open-ended question, mothers described their recommendations and preferences regarding the conveyance of the diagnosis of their infants' cleft lips and/or palates.

The results suggested that the mothers had a strong desire to receive prenatal testing and counseling. This was confirmed by a study conducted by Broder and Trier (1985:159) who stated that subjects suggested that the ideal time for prenatal counseling and diagnosis was "as soon as possible". Mothers furthermore appeared to value parent-to-parent contact and appreciated verbal communication in addition to written information. Written information was valued highly, especially for future reference, but mothers felt that it needed to be in lay terms, clearly organised and needed to be locally relevant. Many of the mothers reported that support group parents should be used in all cases, as they could understand and listen from a parental perspective. Mothers also mentioned that they would have preferred more information at the time of the diagnosis, especially if made prenatally. Sagi, Shilch and Cohen (1992:326) found that the single best predictor for undergoing prenatal testing was the perceived benefit of the test with respect to providing information to the parent.

\section{CONCLUSIONS \& RECOMMENDATIONS}

It was concluded that no meaningful differences existed between the two groups of mothers regarding the emotions experienced, reactions to, or perceptions of the diagnosis, whether it was made pre- or postnatally. Most mothers (11), however, felt that a prenatal diagnosis was preferable, since this allowed time for preparation, both psychologically and practically, and the opportunity to exercise a choice, namely termination of pregnancy, or waiting for the infant to be delivered and managing the problem postnatally. The mothers generally experienced the multidisciplinary team approach in managing their children with a craniofacial anomaly, as being positive. Mothers, who received the diagnoses postnatally, required more support in coping with a team of professionals involved with the child and his or her special needs. The mothers did indicate that their preferences were not always accommodated during the diagnosis and management thereafter. This emphasised the importance of understanding parental preferences which would enable all health care providers involved in the diagnosis and management of children with a cleft lip and/or palate, to meet the needs of their clients in a more sensitive and fulfilling manner (Berk et al. 1999:34).

Due to the exploratory aim of the research and the limited sample size, which was attributed to the fact that prenatal diagnosis of cleft lip is not yet standard practice in South Africa, the degree of external validity of the study was low, and implied that the results could not be generalised to the broader population (Leedy, 1997:34). The technique of scheduled structured interviews may have limited the depth in which the topic was explored (Wood, 1992:2822), but was selected due to the geographical distribution of the mothers who participated in the study, which excluded the use of other research techniques such as focus groups (Wood, 1992:2823).

The results indicated that, irrespective of the time of diagnoses, mothers required support when their infants were diagnosed with a cleft lip and/or palate. The desired support expressed by the mothers consisted of counselling by professionals, parent-to-parent contact and sharing of information in both verbal and written format. The mothers also reported positive experiences of the team approach to individuals with cleft lip and/or palate, which emphasised the importance of involving a multidisciplinary health care team, to provide the best possible care to each affected child and the most effective support to each mother (Guralnick, 1997:232). These findings made a valuable contribution to the field of cleft lip and palate as this issue has not been examined in the South African context to date. The findings had important clinical implications for health care providers for conveying diagnoses, providing information, identifying and utilising support systems and for the management of families and their infants.

The results also had implications for further research. Examining parental experiences of the diagnoses of their children's cleft lips and/or palates in different cultures, religious and income groups would provide information that would aid health care professionals in providing socially and culturally appropriate services in the South African context (Pelser, 1998:81). Investigations of training institutions' curriculum content related to cleft lip and palate and craniofacial disorders for health care providers, could lead to recommendations for improved training, which would, in turn, enhance the quality of 
service provision (Guralnick, 1997:456).

The findings served as a preliminary step in exploring the experiences of mothers when their infants were diagnosed with a cleft lip and/or palate at different stages, and identified valuable clinical guidelines for health care providers in the development of effective and accountable service delivery to families with infants and children with cleft lips and/or palates.

\section{REFERENCES}

BATSHAW, ML 1997: Children with disabilities; 4th edition. Baltimore: Paul H. Brookes.

BENTON, AB; GROSS, AM \& MESSER, SC 1991: Social support networks among families of children with craniofacial anomalies. Health Psychology, 10(1), 1991:252-258.

BERK, NW; MARAZITA, ML \& COOPER, ME 1999: Medical genetics on the cleft palate-craniofacial team: Understanding parental preference. Cleft Palate-Craniofacial Journal, 36(1), 1999:30-35.

BLESS, C \& HIGSON-SMITH, C 1995: Fundamentals of social research methods: An African perspective; 2nd edition. Cape Town: Juta and Co, Ltd.

BLUMENFELD, Z; BLUMENFELD, I \& BRONSHTEIN, M 1999: The early prenatal diagnosis of cleft lip and the decision-making process. Cleft Palate-Craniofacial Journal, 36(2), 1999:105-107.

BRODER, H \& TRIER, WC 1985: Effectiveness of genetic counselling for families with craniofacial anomalies. Cleft Palate-Craniofacial Journal, 22(3), 1985:157-162.

BRONSHTEIN, M; BLUMENFELD, I \& BLUMENFELD, Z 1996: Early prenatal diagnosis of cleft lip and its potential impact on the number of babies with cleft lip. British Journal of Oral and Maxillofacial Surgery, 34(1), 1996:486-487.

BUTLER, KG 1994: Early intervention II. Working with parents and families. Gaithersburg: Aspen Publishers, Inc.

ENDRIGA, MC \& SPELTZ, ML 1997: Face-to-face interaction between infants with craniofacial clefts and their mothers. Journal of Pediatric Psychology, 22(4), 1997:439-453.

GURALNICK, MJ 1997: The effectiveness of early intervention. Baltimore: Paul $\mathrm{H}$ Brookes Publishing Company.

JONES, MC 1999: Prenatai diagnosis of cleft lip and palate: Experiences in Southern California. Cleft Palate-Craniofacial Journal, 36(2), 1999:107-109.

KERLINGER, N 1986: Foundations of behaviour Sciences; third edition. New York: Harcourt Brace Jovanovich College Publishers. KRAHN, GL; HALLUM, A \& KIME, C 1993: Are there good ways to give 'Bad News'? Pediatrics, 91(3), 1993:578-582.

LEEDY, PD 1997: Practical research. Planning and design; 6th edition.
Baltimore: Williams \& Wilkins.

LOUW, B \& KRITZINGER, A 1998: Genetically based communication disorders: Technological advances relevant to the speech-language therapist and Audiologist. Clinica: Applications in Clinical Practice of Communication Pathology, Monograph, 3: 11-23. Pretoria: Department Communication Pathology, University of Pretoria. MCWILLIAMS, BJ; MORRIS, HL \& SHELTON, RL 1990: Cleft pajate speech. Philadelphia: BC Decker Inc

MOUTON, J 1996: Understanding social research. Pretoria: Van Schaik Publishers.

NEUMAN, WL 1997: Social research methods: Qualitative and quantitative approaches; 3rd edition. Boston: Alyn and Bacon.

PALMER, IA \& DU PLESSIS, SM 1996: The facial cleft deformity clinic, University of Pretoria: An evaluation of patient data. Hands-on South Africa, 8(1), 1996:53-56

PELSER, J 1998: Knowledge and attitudes of South African women to prenatal diagnosis. Pretoria: University of Pretoria. (M.Sc. thesis). POPE, AW 1999: Points of risk and opportunity for parents of children with craniofacial conditions. Cleft Palate-Craniofacial Journal, 36(1), 1999:36-39.

SAGI M; SHLLOH, S \& COHEN, T 1992: Application of the health belief model in a study on parents' intentions to utilize prenatal diagnosis of cleft lip and/or palate. American Journal of Medical Genetics, 44(1), 1992:326-333.

SHPRINTZEN, RJ \& BARDACH, J 1995: Cleft palate speech management. A multidisciplinary approach. St. Louis: Mosby Books inc.

SHPRINTZEN, RJ 1997: Genetics, syndromes and communication disorders. San Diego: Singular Publishing Group.

SIMPSON, JL \& ELIAS, S 1993: Essentials of prenatal diagnosis. New York: Churchill Livingston inc.

STEIN, F \& CUTLER, SK 1996: Clinical research in allied health and special education; 3rd edition. Singular Publishing Group: San Diego. STRAUSS, RP; SHARP, MC; LORCH, SC \& KACHALIA, B 1993: Physicians and the communication of "Bad News": Parent experiences of being informed of their child's cleft lip and/or palate. Pediatrics, 96(1), 1993:1-7

TINGEY, C 1989: Implementing early intervention. Baltimore: Brookes Publishing.

WOOD, ML 1992: Focus group interviews in family practice research. Canadian Family Physician, 38(2), 1992:2821-2827. 